\title{
Supporting Information: Quantifying Energy and Water Savings in the U.S. Residential Sector
}

\author{
Christopher M. Chini ${ }^{\mathrm{a}}$, Kelsey L. Schreiber ${ }^{\mathrm{a}}$, Zachary A. Barker ${ }^{\mathrm{a}}$, and Ashlynn S. Stillwell ${ }^{*}$ \\ ${ }^{a}$ Department of Civil and Environment Engineering, University of Illinois at Urbana-Champaign; \\ Urbana, IL, USA \\ *To whom correspondence should be addressed. \\ Email: ashlynn@illinois.edu
}

Phone: 217-244-6507; fax: 217-333-0687

19 pages, 8 tables, 4 figures 
CHINI ET AL. (2016)

Table of Contents: The supporting information is in the following format

\begin{tabular}{lc}
\multicolumn{1}{c}{ Item } & $\begin{array}{c}\text { Page } \\
\text { Number }\end{array}$ \\
\hline List of Efficient WaterSense and ENERGY STAR Appliances and Fixtures & S3 \\
Baseline Appliance and Fixture Costs and Resource Consumption Values & S4 \\
Upgrade Appliance and Fixture Costs and Resource Consumption Values & S5 \\
Direct Costs, Indirect Energy, and Indirect Water for National and City & S6 \\
Comparisons & $\mathrm{S} 7$ \\
Developing Cost Abatement Curves & $\mathrm{S} 10$ \\
Discussion of Water for Electricity & $\mathrm{S} 11$ \\
Chicago's Water Abatement Curve & $\mathrm{S} 12$ \\
Los Angeles' Energy Abatement Curve & $\mathrm{S} 13$ \\
Los Angeles' Water Abatement Curve & $\mathrm{S} 14$ \\
New York City's Energy Abatement Curve & $\mathrm{S} 15$ \\
Water Savings and Abatement Costs & $\mathrm{S} 16$ \\
Utility Rebate Breakdown and Energy and Water Savings Potential & $\mathrm{S} 17$ \\
Utility Rebate Fulfillment Requirements by City & $\mathrm{S} 17$
\end{tabular}


Table S1: We considered 24 different WaterSense or ENERGY STAR appliances and fixtures as part of the study.

ENERGY STAR Air Conditioning, central, single

ENERGY STAR Air Conditioning, central, split (mini, ductless)

ENERGY STAR Audio/Video

ENERGY STAR Ceiling Fan, only

ENERGY STAR Clothes Dryer, ventless or vented electric, standard

ENERGY STAR Clothes Washer, top loading

ENERGY STAR Computer, desktop/all-in-one

ENERGY STAR Dishwasher

ENERGY STAR Freezer, Upright

ENERGY STAR Furnace, gas

ENERGY STAR Heat Pump

ENERGY STAR Refrigerator, Top-Mounted

ENERGY STAR TV, $<40 "$

ENERGY STAR TV, $>40 "$

ENERGY STAR Water Heater, High Efficiency Gas

ENERGY STAR Water Heater, Solar, electric backup

ENERGY STAR Water Heater, Whole Home Gas Tankless

ENERGY STAR Windows

Lighting, 23W CFL

WaterSense Faucet, bathroom

WaterSense Faucet, kitchen

WaterSense Irrigation Controllers

WaterSense Low Flow Toilet

WaterSense Showerhead 
Table S2: We acquired purchase, installation, and maintenance costs as well as energy and water consumption values for baseline appliances and fixtures from various sources including ENERGY STAR, WaterSense, and product details.

\begin{tabular}{|c|c|c|c|c|c|c|c|c|}
\hline Appliance/Fixture & $\begin{array}{c}\text { Purchase } \\
\text { Cost } \\
\text { (\$) }\end{array}$ & $\begin{array}{c}\text { Installation } \\
\text { Cost } \\
\text { (\$) }\end{array}$ & $\begin{array}{l}\text { Lifespan } \\
\quad(y \mathbf{y})\end{array}$ & $\begin{array}{c}\text { Annual } \\
\text { Appliance } \\
\text { Natural Gas } \\
\text { Consumption } \\
\text { (therm/yr) }\end{array}$ & $\begin{array}{c}\text { Annual } \\
\text { Appliance } \\
\text { Electricity } \\
\text { Consumption } \\
\text { (kWh/yr) } \\
\end{array}$ & $\begin{array}{c}\text { Annual } \\
\text { Maintenance } \\
\text { Cost } \\
(\$ / y r)\end{array}$ & $\begin{array}{c}\text { Annual } \\
\text { Water } \\
\text { Consumption } \\
\text { (gal/yr) }\end{array}$ & $\begin{array}{c}\text { Annual Hot } \\
\text { Water } \\
\text { Consumption } \\
\text { (gal/yr) }\end{array}$ \\
\hline Equation Symbol & $\boldsymbol{P}$ & $I$ & $t$ & $E_{N G}$ & $E_{\text {elec }}$ & $M$ & $V$ & $V_{\text {hot }}$ \\
\hline Air Conditioning & $1,025.00$ & 506.00 & 18.4 & 0 & 2,238 & 67.00 & 0 & 0 \\
\hline Cable Box & 99.00 & - & 2 & 0 & 145 & - & 0 & 0 \\
\hline Ceiling Fan & 99.00 & - & 13.8 & 0 & 157 & - & 0 & 0 \\
\hline Clothes Dryer & 749.00 & - & 15.9 & 0 & 1,000 & 3.00 & 0 & 0 \\
\hline Clothes Washer & 599.00 & - & 14.2 & 0 & 300 & - & 19,512 & 5,424 \\
\hline Desktop Computer & 350.00 & - & 5.9 & 0 & 237 & - & 0 & 0 \\
\hline Laptop Computer & 200.00 & - & 5.5 & 0 & 72 & - & 0 & 0 \\
\hline Dishwasher & 244.00 & 362.00 & 15.4 & 0 & 330 & - & 730 & 730 \\
\hline Bathroom Faucet & 81.00 & - & 15 & 0 & 0 & - & 19,513 & 14,186 \\
\hline Kitchen Faucet & 15.00 & - & 15 & 0 & 0 & - & 6,504 & 4,729 \\
\hline Upright Freezer & 849.00 & - & 21.7 & 0 & 479 & 5.00 & 0 & 0 \\
\hline Chest Freezer & 599.00 & - & 21.7 & 0 & 306 & 3.00 & 0 & 0 \\
\hline Furnace & $1,094.00$ & 714.00 & 15 & 458 & 0 & 46.00 & 0 & 0 \\
\hline Irrigation Control & 55.00 & - & 10 & 0 & 0 & - & 46,282 & 0 \\
\hline $\begin{array}{l}\text { Incandescent } \\
\text { Lighting }\end{array}$ & 85.05 & - & 1.8 & 0 & 70 & - & 0 & 0 \\
\hline Refrigerator & 468.00 & - & 16.2 & 0 & 373 & 8.00 & 0 & 0 \\
\hline Showerhead & 20.00 & 362.00 & 15.4 & 0 & 330 & - & 16,936 & 12,380 \\
\hline Audio/Video & 100.00 & - & 7 & 0 & 104 & - & 0 & 0 \\
\hline TV $<40 "$ & 230.00 & - & 7.4 & 0 & 301 & - & 0 & 0 \\
\hline TV $>40^{\prime \prime}$ & 400.00 & - & 7.4 & 0 & 455 & - & 0 & 0 \\
\hline Toilet & 343.00 & - & 50 & 0 & 0 & - & 11,797 & 0 \\
\hline NG Water Heater & 499.00 & 326.00 & 13 & 261 & 0 & - & 0 & 0 \\
\hline $\begin{array}{l}\text { Electric Water } \\
\text { Heater }\end{array}$ & 395.00 & 307.00 & 13 & 0 & 4857 & - & 0 & 0 \\
\hline Windows & 135.00 & 500.00 & 15 & 0 & 2,658 & - & 0 & 0 \\
\hline Wireless Router & 130.00 & - & 5 & 0 & 88 & - & 0 & 0 \\
\hline
\end{tabular}


Table S3: We acquired purchase, installation, and maintenance costs as well as energy and water consumption values for upgrade appliances and fixtures from various sources including ENERGY STAR, WaterSense, and product details.

\begin{tabular}{|c|c|c|c|c|c|c|c|c|}
\hline Appliance/Fixture & $\begin{array}{l}\text { Purchase } \\
\text { Cost } \\
\text { (\$) }\end{array}$ & $\begin{array}{c}\text { Installation } \\
\text { Cost } \\
\text { (\$) }\end{array}$ & $\begin{array}{c}\text { Lifespan } \\
\text { (yr) }\end{array}$ & $\begin{array}{c}\text { Annual } \\
\text { Appliance } \\
\text { Natural Gas } \\
\text { Consumption } \\
\text { (therm/yr) }\end{array}$ & $\begin{array}{c}\text { Annual } \\
\text { Appliance } \\
\text { Electricity } \\
\text { Consumption } \\
\text { (kWh/yr) }\end{array}$ & $\begin{array}{c}\text { Annual } \\
\text { Maintenance } \\
\text { Cost } \\
(\$ / y r)\end{array}$ & $\begin{array}{c}\text { Annual } \\
\text { Water } \\
\text { Consumption } \\
\text { (gal/yr) }\end{array}$ & $\begin{array}{c}\text { Annual Hot } \\
\text { Water } \\
\text { Consumption } \\
\text { (gal/yr) }\end{array}$ \\
\hline Equation Symbol & $P$ & $I$ & $t$ & $E_{N G}$ & $E_{\text {elec }}$ & $M$ & $V$ & $V_{\text {hot }}$ \\
\hline $\begin{array}{l}\text { ENERGY STAR Air } \\
\text { Conditioning } \\
\end{array}$ & $3,370.00$ & 506.00 & 14 & 0 & 2,078 & 67.00 & 0 & 0 \\
\hline $\begin{array}{l}\text { ENERGY STAR Cable } \\
\text { Box }\end{array}$ & 99.00 & - & 2 & 0 & 94 & - & 0 & 0 \\
\hline $\begin{array}{l}\text { ENERGY STAR } \\
\text { Ceiling Fan } \\
\end{array}$ & 79.00 & - & 10 & 0 & 152 & - & 0 & 0 \\
\hline $\begin{array}{l}\text { ENERGY STAR } \\
\text { Clothes Dryer }\end{array}$ & 799.00 & - & 16 & 0 & 608 & 3.00 & 0 & 0 \\
\hline $\begin{array}{l}\text { ENERGY STAR } \\
\text { Clothes Washer }\end{array}$ & $1,199.00$ & - & 10 & 0 & 120 & - & 8,362 & 4,430 \\
\hline $\begin{array}{l}\text { ENERGY STAR } \\
\text { Desktop Computer }\end{array}$ & 450.00 & - & 5.9 & 0 & 166 & - & 0 & 0 \\
\hline $\begin{array}{l}\text { ENERGY STAR } \\
\text { Laptop Computer }\end{array}$ & 250.00 & - & 5.5 & 0 & 62 & - & 0 & 0 \\
\hline $\begin{array}{l}\text { ENERGY STAR } \\
\text { Dishwasher }\end{array}$ & 539.00 & 362.00 & 10 & 0 & 295 & - & 620 & 621 \\
\hline $\begin{array}{l}\text { WaterSense Bathroom } \\
\text { Faucet }\end{array}$ & 58.00 & - & 10 & 0 & 0 & - & 13,304 & 9,672 \\
\hline $\begin{array}{l}\text { WaterSense Kitchen } \\
\text { Faucet }\end{array}$ & 31.00 & - & 10 & 0 & 0 & - & 5322 & 3,869 \\
\hline $\begin{array}{l}\text { ENERGY STAR } \\
\text { Upright Freezer }\end{array}$ & 989.00 & - & 12 & 0 & 431 & 5.00 & 0 & 0 \\
\hline $\begin{array}{l}\text { ENERGY STAR Chest } \\
\text { Freezer }\end{array}$ & 749.00 & - & 12 & 0 & 275 & 3.00 & 0 & 0 \\
\hline $\begin{array}{l}\text { ENERGY STAR } \\
\text { Furnace }\end{array}$ & $1,599.00$ & $1,454.00$ & 18 & 402 & 0 & 46.00 & 0 & 0 \\
\hline $\begin{array}{l}\text { WaterSense Irrigation } \\
\text { Controllers }\end{array}$ & 239.00 & - & 30 & 0 & 0 & - & 37,482 & 0 \\
\hline CFL Lighting & 146.00 & - & 14.9 & 0 & 15 & - & 0 & 0 \\
\hline $\begin{array}{l}\text { ENERGY STAR } \\
\text { Refrigerator }\end{array}$ & 599.00 & - & 12 & 0 & 336 & 8.00 & 0 & 0 \\
\hline $\begin{array}{l}\text { WaterSense } \\
\text { Showerhead }\end{array}$ & 34.00 & - & 10 & 0 & 295 & - & 13,549 & 9,904 \\
\hline $\begin{array}{l}\text { ENERGY STAR } \\
\text { Audio/Video }\end{array}$ & 150.00 & - & 7 & 0 & 21 & - & 0 & 0 \\
\hline $\begin{array}{l}\begin{array}{l}\text { ENERGY STAR TV } \\
<40^{\prime \prime}\end{array} \\
\end{array}$ & 277.00 & - & 6 & 0 & 79 & - & 0 & 0 \\
\hline $\begin{array}{l}\text { ENERGY STAR TV } \\
>40^{\prime \prime}\end{array}$ & 499.00 & - & 6 & 0 & 151 & - & 0 & 0 \\
\hline $\begin{array}{l}\text { WaterSense Low Flow } \\
\text { Toilet }\end{array}$ & 297.00 & - & 20 & 0 & 0 & - & 9,437 & 0 \\
\hline $\begin{array}{l}\text { ENERGY STAR Heat } \\
\text { Pump Water Heater }\end{array}$ & 999.00 & 301.00 & 10 & 0 & 2195 & - & 0 & 0 \\
\hline $\begin{array}{l}\text { ENERGY STAR Solar } \\
\text { Water Heater }\end{array}$ & $3,996.00$ & 300.00 & 20 & 0 & 2429 & - & 0 & 0 \\
\hline $\begin{array}{l}\text { ENERGY STAR } \\
\text { Tankless Gas }\end{array}$ & $1,408.00$ & 585.00 & 20 & 183 & 0 & - & 0 & 0 \\
\hline $\begin{array}{l}\text { ENERGY High } \\
\text { Efficiency Gas }\end{array}$ & 699.00 & 601.00 & 13 & 242 & 0 & - & 0 & 0 \\
\hline $\begin{array}{l}\text { ENERGY STAR } \\
\text { Windows }\end{array}$ & 165.00 & 500.00 & 20 & 0 & 2,195 & - & 0 & 0 \\
\hline $\begin{array}{l}\text { ENERGY STAR } \\
\text { Wireless Router }\end{array}$ & 199.00 & - & 5 & 0 & 73 & - & 0 & 0 \\
\hline
\end{tabular}


CHINI ET AL. (2016)

Table S4: Pricing, indirect energy consumption, and indirect water consumption vary widely across the country.

\begin{tabular}{|c|c|c|c|c|}
\hline Item (variable) & $\begin{array}{l}\text { National } \\
\text { Averages }\end{array}$ & Chicago & $\begin{array}{l}\text { New } \\
\text { York } \\
\text { City }\end{array}$ & $\begin{array}{c}\text { Los } \\
\text { Angeles }\end{array}$ \\
\hline Electricity: Energy Cost $\$ / \mathbf{k W h}\left(\mathrm{c}_{\text {elec }}\right)$ & $\$ 0.12^{1}$ & $\$ 0.16^{4}$ & $\$ 0.19^{4}$ & $\$ 0.21^{4}$ \\
\hline Natural Gas: Energy Cost $\$ / M M B t u,\left(c_{N G}\right)$ & $\$ 10.11^{2}$ & $\$ 11.86^{4}$ & $\$ 12.00^{4}$ & $\$ 14.30^{4}$ \\
\hline Drinking Water Cost \$/kgal, (c $\left.\mathbf{c}_{\mathrm{Dw}}\right)$ & $\$ 4.35^{3}$ & $\$ 3.81^{5}$ & $\$ 4.95^{6}$ & $\$ 6.60^{7}$ \\
\hline Wastewater Treatment Cost \$/kgal, (c $\left.\mathrm{c}_{\mathrm{ww}}\right)$ & $\$ 5.38^{3}$ & $\$ 3.81^{5}$ & $\$ 7.86^{6}$ & $\$ 5.66^{7}$ \\
\hline Electricity for Drinking Water (kWh/MG), $\left(\mathrm{e}_{\mathrm{DW}}\right)$ & $1750^{8}$ & $208^{9}$ & $589^{10}$ & $5953^{11}$ \\
\hline Electricity for Wastewater (kWh/MG) & $2000^{8}$ & $950^{9}$ & $4317^{10}$ & $1028^{11}$ \\
\hline NG for Drinking Water (therm/MG) & $6^{8}$ & $68.4^{9}$ & $2.69^{10}$ & $\mathrm{n} / \mathrm{a}$ \\
\hline NG for Wastewater (therm/MG) & $30^{8}$ & $3.2^{9}$ & $12.39^{10}$ & $\mathrm{n} / \mathrm{a}$ \\
\hline Water consumed for Electricity (Gal/MWh) & $5.9^{12}$ & $7.4^{12}$ & $0.9^{12}$ & $1.5^{12}$ \\
\hline Unaccounted for Water $(\%)$ & $16 \%{ }^{13}$ & $7.55 \%{ }^{14}$ & $21 \%{ }^{15}$ & $6.02 \%^{16}$ \\
\hline
\end{tabular}

Notes:

1. EIA (2012) "Average Price of Electricity to Ultimate Customers",

2. EIA (2012) "Natural Gas Prices"

3. Determined via national survey of top 100 most populous cities (various references)

4. United States Department of Labor, Bureau of Labor Statistics ${ }^{3-5}$

5. City of Chicago, Water Sewer Rates ${ }^{6}$

6. New York City Water Board, Rates and Regulations ${ }^{7}$

7. Los Angeles Department of Water and Power, Water Rates ${ }^{8}$

8. AWWA RF (2007), "Energy Index Development for Benchmarking Water and Wastewater Utilities"

9. MWRD Data and Open Records Requests from the City of Chicago

10. New York Water Environment Association (2013), "Transforming Wastewater Operations into Resource Recovery: NYCDEP's Strategies for Energy Neutral Operations" $" 10$

11. H. Blanco, et al. (2012), "Water Supply Scarcity in Southern California: Assessing Water District Level Strategies" 11

12. EIA Form $923^{12}$, see following section for methodology

13. Thornton, et al. (2008), "Water loss control"13

14. Illinois Department of Natural Resources (IDNR) (2012), "Annual Water Use Audit Form (LMO-2),"6

15. New York City Department of Environmental Protection (2012), "Water Conservation Report" "

16. Los Angeles Department of Water and Power, (2010) "Urban Water Management Plan"8 


\section{Developing Cost Abatement Curves}

The following describes Equation 1 from the main text in more detail. Equation 1 describes the computation of an abatement cost for each appliance and fixture. Equation 1 from the main text is:

$$
\text { Abatement Cost }\left[\frac{\$}{\text { unit }}\right]=\frac{\text { Upgrade Direct Cost }- \text { Replacement Direct Cost }}{\text { Annual Direct and Indirect Energy or Water Savings }}
$$

Direct costs include annualized purchase and installation costs, annual maintenance costs, and annual resource consumption costs. To annualize costs, we utilize the product's lifespan and estimate the interest rate to be equivalent to average annual inflation of $3.2 \%$. The equation is the same for both the upgrade and replacement appliance or fixture and draws from Tables S2-S4 for data. Direct cost is computed as follows:

$$
\text { Direct Cost }=(P+I) *\left(\frac{i(1+i)^{t}}{(1+i)^{t}-1}\right)+M+\left[c_{N G} E_{N G}+c_{\text {elec }} E_{\text {elec }}+\left(c_{D W}+c_{W W}\right) V\right]
$$

This equation serves to explain the numerator of the abatement cost equation. The denominator is the sum of the direct and indirect energy or water savings of each appliance or fixture. The energy savings include energy for operating the appliance, energy for heating water for the appliance/fixture, drinking water treatment, and energy for wastewater treatment. For the case of irrigation, the energy saved from wastewater treatment is omitted. The volume of water saved includes water saved through efficiency, water for natural gas, water for thermoelectric power cooling, and unaccounted for water.

In the case of energy savings, there are multiple units to consider: therms for natural gas and $\mathrm{kWh}$ for electricity. We assume a 0.45 efficiency factor for converting natural gas therms to electricity:

$$
\text { Direct Energy Consumption }=0.45 * E_{N G} * 29.3 \frac{\mathrm{kWh}}{\text { therm }}+E_{\text {elec }}
$$

\section{National Average Example Calculation (Clothes Washer with Natural Gas Water Heater)}

The following example steps through the computation of two abatement costs (water and energy) for the national average clothes washer. The data are from Tables S1-S3 and values given in the main text.

1) Calculate annual direct and indirect energy savings

First, using heating efficiencies determine the natural gas required to heat hot water for both replacement and upgrade appliances.

$$
\begin{gathered}
E_{N G}(\text { Replacement })=V_{\text {hot }} * 0.011 \frac{\text { therm }}{\text { gal }}=5,424 \mathrm{gal} * 0.011 \frac{\text { therm }}{\text { gal }} \\
=60.32 \text { therms }
\end{gathered}
$$




$$
E_{N G}(\text { Upgrade })=V_{\text {hot }} * 0.011 \frac{\text { therm }}{\text { gal }}=4430 \mathrm{gal} * 0.011 \frac{\text { therm }}{\text { gal }}=49.26 \text { therms }
$$

Next, calculate the total direct energy consumption in terms of $\mathrm{kWh}$ for each.

$$
\begin{gathered}
\text { Direct Energy }(\text { Replacement })=0.45 * 60.32 \text { therms } * 29.3 \frac{\mathrm{kWh}}{\text { therm }}+300 \mathrm{kWh} \\
=1,095 \mathrm{kWh} \\
\text { Direct Energy }(\text { Upgrade })=0.45 * 49.26 \text { therm } * 29.3 \frac{\mathrm{kWh}}{\text { therm }}+120 \mathrm{kWh} \\
=770 \mathrm{kWh}
\end{gathered}
$$

Calculate the indirect energy consumption using water consumption.

$$
\begin{gathered}
\text { Indirect Energy }(\text { Replacement })=V\left(3750 \frac{\mathrm{kWh}}{M G}+0.45 * 29.3 \frac{\mathrm{kWh}}{\text { therm }} * 36 \frac{\text { therm }}{M G}\right) \\
=19,512 \mathrm{gal}\left(4,224.66 \frac{\mathrm{kWh}}{M G}\right)=82.4 \mathrm{kWh} \\
\text { Indirect Energy (Upgrade) }=8,362 \mathrm{gal}\left(4,224.66 \frac{\mathrm{kWh}}{\mathrm{MG}}\right)=35.3 \mathrm{kWh}
\end{gathered}
$$

The total energy savings is then the replacement consumption less the upgrade consumption.

$$
\text { Energy Savings }=(1095+82.4)-(35.3+770)=372 \mathrm{kWh}
$$

2) Calculate annual direct costs of upgrade and replacement appliance or fixture

Direct Cost $_{\text {Replacement }}$

$$
=\$ 559\left(\frac{i(1+i)^{t}}{(1+i)^{t}-1}\right)+c_{N G} E_{N G}+c_{\text {elec }} E_{\text {elec }}+\left(c_{D W}+c_{W W}\right) V
$$

Direct Cost $_{\text {Replacement }}$

$$
\begin{aligned}
& =\$ 559\left(\frac{0.0322(1+0.0322)^{14.2}}{(1+0.0322)^{14.2}-1}\right)+\frac{\$ 1.011}{\text { therm }} * 60.32 \text { therm }+\frac{\$ 0.12}{k W h} \\
& * 300 \mathrm{kWh}+\left(9.73 \frac{\$}{\mathrm{kgal}}\right) * 19,512 \mathrm{gal}=\$ 340.06 / \mathrm{yr}
\end{aligned}
$$

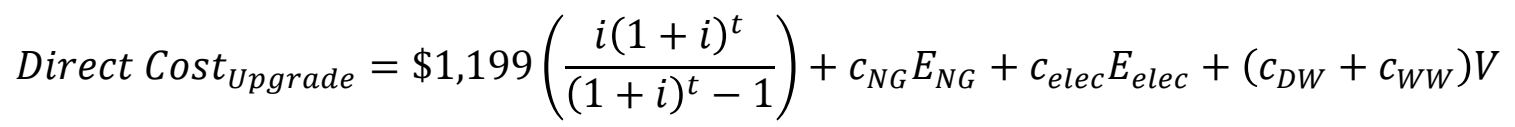
Direct Cost $_{\text {Upgrade }}$

$$
\begin{aligned}
& =\$ 1,199\left(\frac{0.0322(1+0.0322)^{14.2}}{(1+0.0322)^{14.2}-1}\right)+\frac{\$ 1.011}{\text { therm }} * 49.26 \text { therm }+\frac{\$ 0.12}{k W h} \\
& * 120 \mathrm{kWh}+\left(9.73 \frac{\$}{\mathrm{kgal}}\right) * 8,362 \mathrm{gal}=\$ 287.71 / \mathrm{yr}
\end{aligned}
$$

The difference in costs per the numerator in the first equation of the section (Abatement Cost) is calculated as follows: 
Upgrade Direct Cost - Replacement Direct Cost $=287.71-340.06$

$$
=-\$ 52.35 / y r
$$

3) Calculate direct and indirect water savings

The water consumption for each appliance is the sum of direct water savings and indirect water savings, consisting of water for electricity generation, water for natural gas extraction, and water loss as a percent of total treated water.

Water Consumption (Replacement)

$$
=V+0.3 \frac{\text { gal }}{\text { therm }} * E_{N G}+5.9 \frac{g a l}{M W h} E_{\text {elec }}+V\left(\frac{1}{1-p}-1\right)
$$

Where $p$ is the percent of unaccounted for water

Water Consumption (Replacement)

$$
\begin{aligned}
& =19,512 \mathrm{gal}+0.3 \frac{\mathrm{gal}}{\text { therm }} * 60.32 \text { therms }+5.9 \frac{\mathrm{gal}}{\mathrm{MWh}} * 300 \mathrm{kWh} \\
& +19,512 \mathrm{gal}\left(\frac{1}{1-0.16}-1\right)=23,248 \mathrm{gal}
\end{aligned}
$$

Water Consumption (Upgrade)

$$
\begin{aligned}
& =8,362 \mathrm{gal}+0.3 \frac{\mathrm{gal}}{\text { therm }} * 49.26 \text { therms }+5.9 \frac{\mathrm{gal}}{\mathrm{MWh}} * 120 \mathrm{kWh} \\
& +8,362 \mathrm{gal}\left(\frac{1}{1-0.16}-1\right)=9,971 \mathrm{gal}
\end{aligned}
$$

Water savings are the net difference between the two options.

$$
\text { Water Savings }=\text { Replacement }- \text { Upgrade }=13,277 \mathrm{gal}
$$

\section{4) Determine abatement cost for appliance}

Using the first equation of the section, we use the values for direct cost, water savings, and energy savings to determine the abatement costs of the clothes washer

$$
\begin{aligned}
& \text { Energy Abatement Cost }\left[\frac{\$}{\mathrm{kWh}}\right]=\frac{-\frac{\$ 52.35}{y r}}{372 \frac{\mathrm{kWh}}{y r}}=-\$ 0.14 / \mathrm{kWh} \\
& \text { Water Abatement Cost }\left[\frac{\$}{\mathrm{gal}}\right]=\frac{-\frac{\$ 52.35}{y r}}{13,277 \frac{\mathrm{gal}}{\mathrm{yr}}}=-\$ 0.004 / \mathrm{gal}
\end{aligned}
$$




\section{Water for Electricity}

The following methodology and figures show the calculation of water consumption for thermoelectric power generation (indirect water). First, we calculate on the national average and then on a local scale. For the local scale, we estimate that power plants within a radius of 25 miles from the municipal statistical area (MSA) are relevant to the calculation of indirect water calculation. The water consumed at thermoelectric power plants within this area is taken out of the local water cycle and is, therefore, not available for the municipality's use.

1. In ArcMap:

a. Download the Metropolitan Statistical Areas (MSAs) for the USA

b. Download shapefiles for the power plants

2. In Python:
a. Select the desired MSA
b. Select power plants by location using 25 miles as a buffer
c. Exports the EIA IDs to a CSV file
d. Prints the power plants by fuel type
e. Prints the generation by renewables

3. In Excel:

a. Create a CSV file from the EIA cooling data combining the years 2011-13

b. Create a CSV file from the EIA generation data combining the years 2011-13

4. In MATLAB:
a. Read in the selected power plant, cooling, and generation CSVs
b. Average the withdrawal, consumption, and generation for each power plant
c. Sum the withdrawal, consumption, and generation for the selected power plants
d. Calculate water for electricity efficiency

Table S5: The consumption of water at the national scale at thermoelectric power plants is 5.9 gallons per MWh. The consumptive values vary regionally with Chicago consuming more than the national average and New York and Los Angeles consuming less.

National

Average Chicago New York Los Angeles

\begin{tabular}{lcccc}
\hline Generation (MWh/yr) & $3,241,400,000$ & $124,308,260$ & $114,160,000$ & $39,100,000$ \\
\hline Withdrawal (GPM) & $2,061,100$ & 121,780 & 99,380 & 28,463 \\
\hline Consumption (GPM) & 36,283 & 1,756 & 199 & 108 \\
\hline $\begin{array}{l}\text { Withdrawal Efficiency } \\
\text { (Gal/MWh) }\end{array}$ & 334.2 & 515.9 & 457.5 & 382.6 \\
\hline $\begin{array}{l}\text { Consumption Efficiency } \\
\text { (Gal/MWh) }\end{array}$ & 5.9 & 7.4 & 0.9 & 1.5 \\
\hline
\end{tabular}


Figures S1-S4 represent the remaining regional abatement curves that are not contained within the main manuscript (See Chini, et al. 2016 section Results: City Abatement Curves). The water abatement curves illustrate the total annual volume of direct and indirect water savings available for each city and its accompanying abatement cost (\$/gal). Similarly, the energy abatement curves show the direct and indirect energy savings with similar trends to those in the main manuscript. Variation between Supporting Information Figures S1-S4 and the national and citylevel figures in the main manuscript is due to the variation in embedded energy in water treatment, unaccounted for water, and pricing of water and energy.

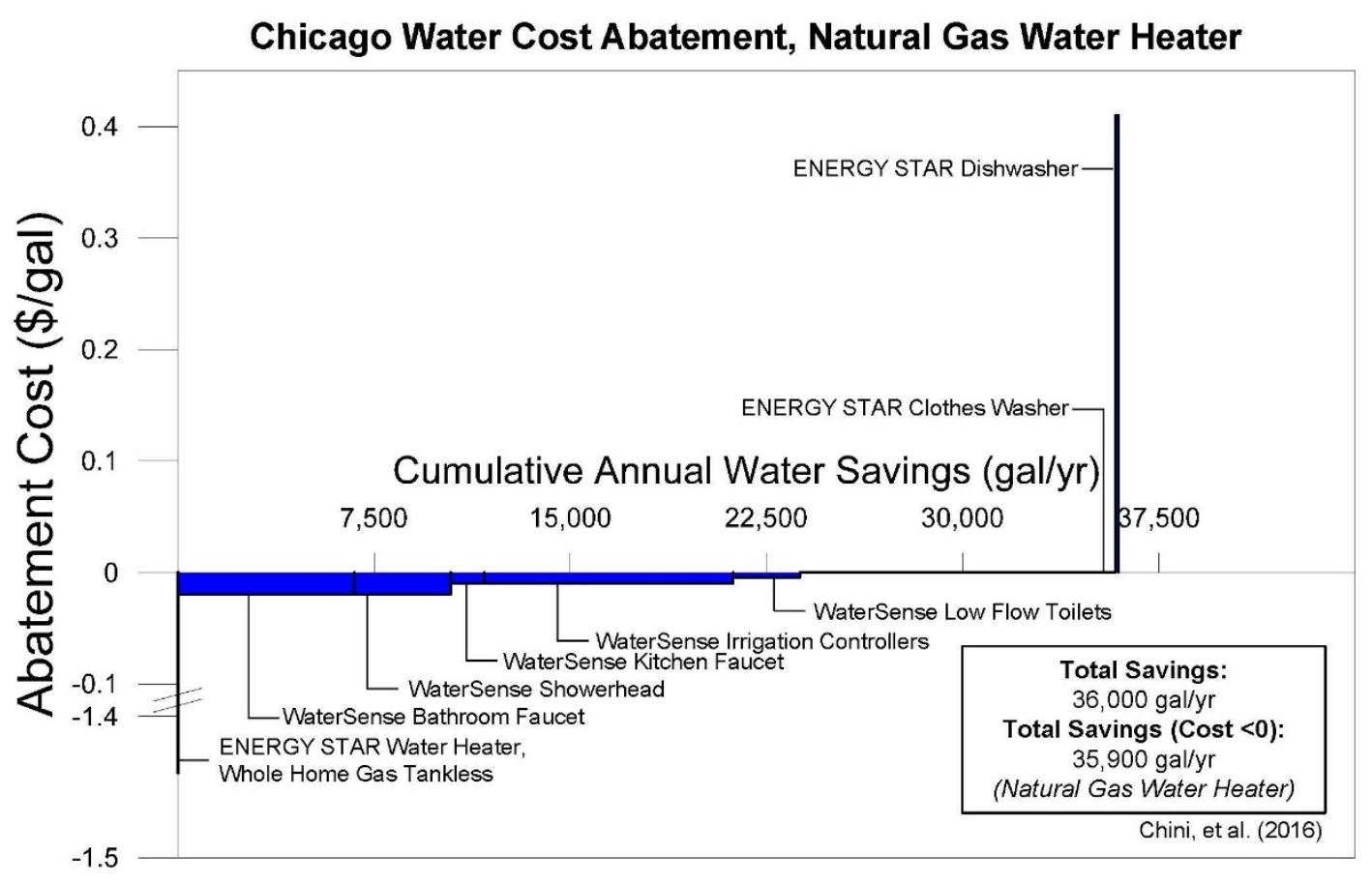

Figure S1: Cost abatement curve for water savings in Chicago, IL 


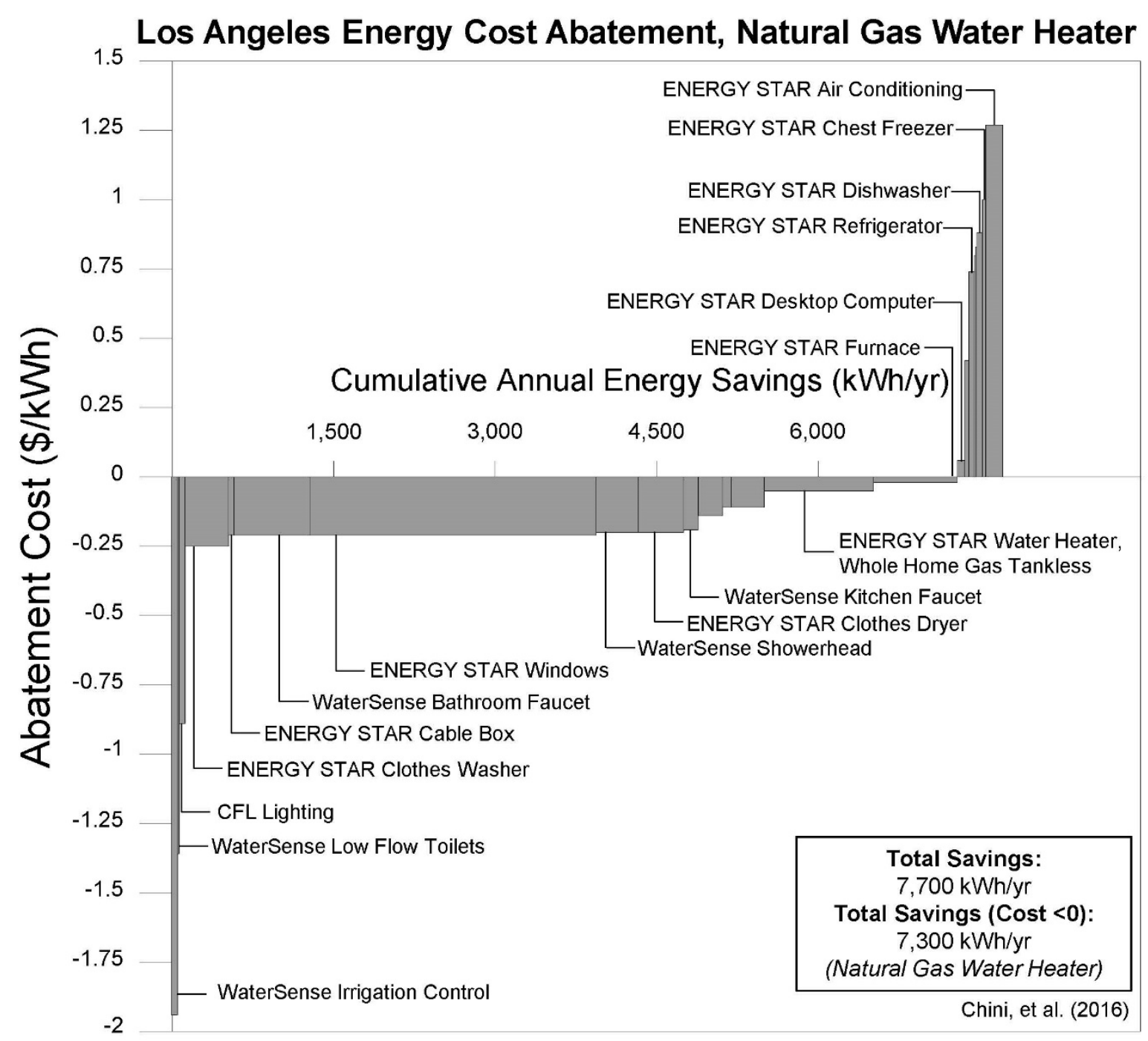

Figure S2: Cost abatement curve for energy in Los Angeles, CA 
CHINI ET AL. (2016)

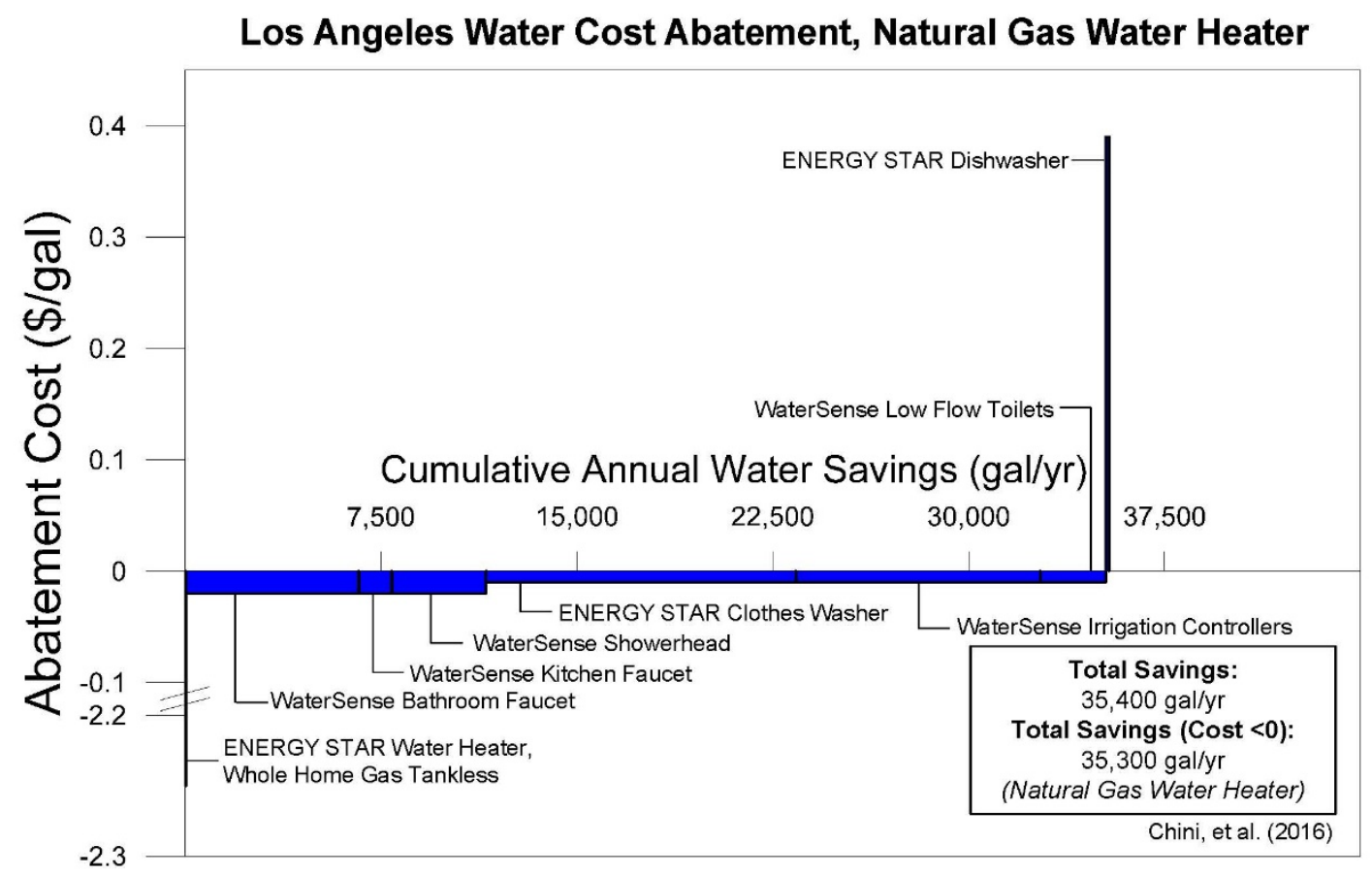

Figure S3: Cost abatement curve for water in Los Angeles, CA 


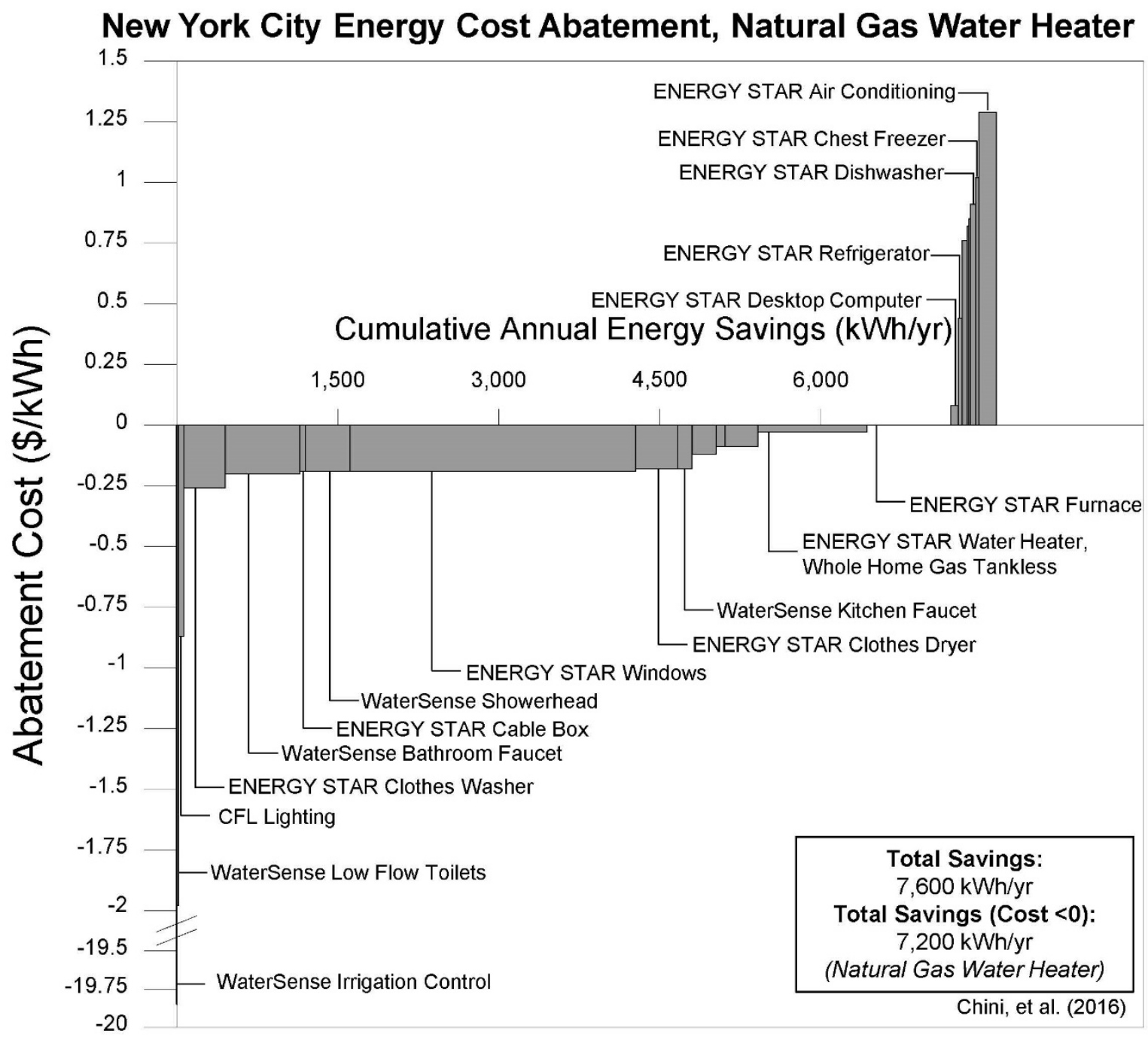

Figure S4: Cost abatement curve for energy in New York City, NY 
Table S6 details the water savings and abatement costs for appliances and fixtures. Due to the large volume of savings, appliances and fixtures with savings of 20 gallons per year or less were not plotted on the cost abatement curves. The following table shows these minimal savings associated with indirect water for multiple appliances and fixtures for the National, Chicago, Los Angeles, and New York City case studies. All of the savings represent a natural gas water heater.

Table S6: Annual indirect water contributed to minor potential volume savings for nine different appliances. These appliances are not plotted on the water cost abatement curves due to issues of scale.

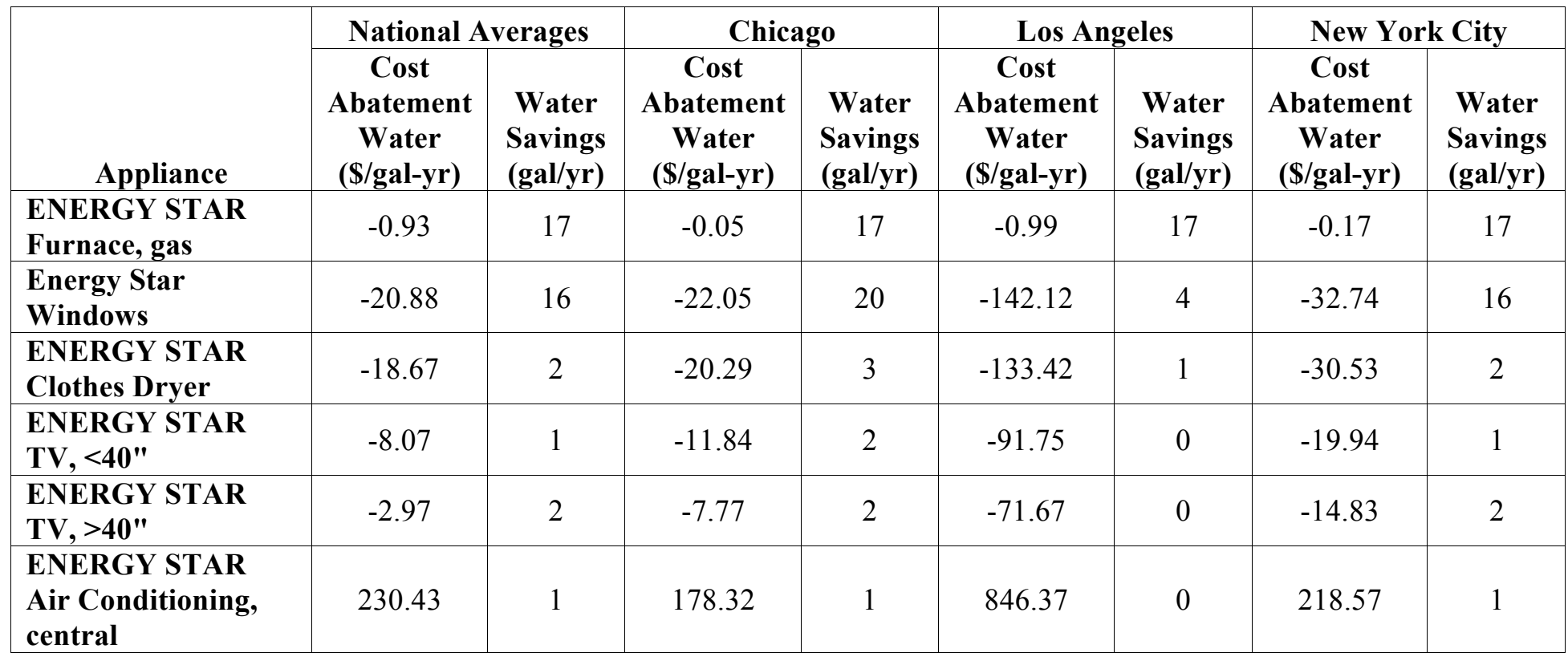


Table S7 outlines the rebates offered through different utility providers in each of the local case study cities, as well as the possible energy and water savings from appliance upgrades. Multiple rebates might be offered for the same appliance; however, we assume that only one rebate may be applied for and granted. The table also only considers appliances utilized in the cost abatement analysis of an average residential space. This table allows for comparisons of dollars spent to $\mathrm{kWh}$ and gallons of energy and water savings, respectively.

Table S7: Utility Rebate Breakdown and Energy and Water Savings Potential. Electric Utility

Company Rebates, Natural Gas Company Rebates, Water and/or Wastewater Company

Rebates. (Commonwealth Edison Company 2015 ${ }^{14}$, Consolidated Edison $2015^{15}$, L.A.

Department of Water and Power 2013 ${ }^{16}$, Metropolitan Water Reclamation District of Greater

Chicago $2015^{17}$, Peoples Gas $2015^{18}$, Southern California Gas Company $2015^{19}$, The City of New York $2015^{20}$ )

\begin{tabular}{|c|c|c|c|c|c|c|}
\hline \multirow[t]{2}{*}{ Appliance/Fixture } & \multicolumn{2}{|c|}{ Chicago } & \multicolumn{2}{|c|}{ Los Angeles } & \multicolumn{2}{|c|}{ New York City } \\
\hline & $\begin{array}{c}\text { Rebate } \\
\text { amount } \\
\text { (\$) }\end{array}$ & $\begin{array}{c}\text { Annual } \\
\text { savings } \\
\text { kWh/ } \\
\text { gallons }\end{array}$ & $\begin{array}{c}\text { Rebate } \\
\text { amount } \\
\text { (\$) }\end{array}$ & $\begin{array}{c}\text { Annual } \\
\text { savings } \\
\text { kWh/ } \\
\text { gallons }\end{array}$ & $\begin{array}{c}\text { Rebate } \\
\text { amount } \\
\text { (\$) }\end{array}$ & $\begin{array}{c}\text { Annual } \\
\text { savings } \\
\mathbf{k W h} / \\
\text { gallons }\end{array}$ \\
\hline Central A/C & $\$ 300$ & 160 & $\$ 300$ & 160 & $\$ 100$ & 160 \\
\hline Clothes Dryer & $\$ 50$ & 390 & - & - & - & - \\
\hline Clothes Washer & $\$ 50$ & $490 / 12,000$ & $\$ 300$ & $450 / 12,000$ & - & - \\
\hline Freezer & $\$ 25$ & 31 & - & - & - & - \\
\hline Furnace, natural gas & $\$ 200$ & $5,600 / 130$ & $\$ 200$ & $5,600 / 130$ & $\$ 600$ & $5,600 / 130$ \\
\hline Irrigation Control & - & - & $\$ 200$ & $61 / 9,400$ & - & - \\
\hline Rain Barrel & $\$ 28.32$ & - & - & - & - & - \\
\hline Refrigerator & $\$ 50$ & 37 & $\$ 65$ & 37 & $\$ 50$ & 37 \\
\hline Refrigerator/Freezer & - & - & $\$ 50$ & - & - & - \\
\hline Showerhead & - & - & $\$ 15$ & $530 / 3,600$ & - & - \\
\hline Television, <40" & - & - & $\$ 10$ & 220 & - & - \\
\hline Television, >40" & - & - & $\$ 10$ & 300 & - & - \\
\hline Toilet & - & - & $\$ 150$ & $16 / 2,500$ & $\$ 125$ & $16 / 3,000$ \\
\hline $\begin{array}{l}\text { Water Heater, } \\
\text { natural gas }\end{array}$ & $\$ 150$ & $3,100 / 770$ & $\$ 100$ & $3,100 / 770$ & - & - \\
\hline Windows & - & - & $\$ 9$ & 2,700 & - & - \\
\hline Totals & $\$ 853$ & $\begin{array}{l}9,810 \\
\text { kWh } \\
12,900 \text { gal }\end{array}$ & $\$ 1410$ & $\begin{array}{l}13,200 \\
\text { kWh } \\
28,400 \text { gal }\end{array}$ & $\$ 875$ & $\begin{array}{l}5,810 \\
\text { kWh } \\
3,130 \text { gal } \\
\end{array}$ \\
\hline
\end{tabular}


Table S8 shows the appliance efficiency standards necessary to be eligible to receive the rebates offered through utility companies in each of the local case study cities. Utilities offer adaptive rebates that increase as the installed appliance becomes more efficient. The requirements listed (and corresponding dollar amount in Table S7) most closely match the requirements of the efficient case in the abatement curve analysis.

Table S8: Utility Rebate Fulfillment Requirements by City. (Commonwealth Edison Company $2015^{14}$, Consolidated Edison $2015^{15}$, L.A. Department of Water and Power 2013 ${ }^{16}$, Peoples Gas $2015^{18}$, Southern California Gas Company $2015^{19}$, The City of New York 2015 ${ }^{20}$ )

\begin{tabular}{|l|l|l|l|}
\hline Appliance/Fixture & Chicago & Los Angeles & New York City \\
\hline Central A/C & $\geq 14.5$ SEER & 15 SEER & $\geq 15$ SEER \\
\hline Clothes Dryer & $\begin{array}{l}\geq 4.4 \mathrm{ft}^{3} \\
\text { ENERGY } \\
\text { STAR labeled }\end{array}$ & - & - \\
\hline Clothes Washer & $\begin{array}{l}\text { ENERGY } \\
\text { STAR labeled }\end{array}$ & $\begin{array}{l}\text { ENERGY } \\
\text { STAR labeled }\end{array}$ & \\
\hline Freezer & $\geq 7.75 \mathrm{ft}^{3}$ & - & - \\
& $\begin{array}{l}\text { ENERGY } \\
\text { STAR labeled }\end{array}$ & & \\
\hline Furnace, natural gas & $\geq 95 \%$ AFUE & $\geq 95 \%$ AFUE & $\geq 94$ AFUE \\
\hline Irrigation Control & - & $<1$ acre & - \\
\hline Rain Barrel & None & - & - \\
\hline Refrigerator & $\geq 7.75 \mathrm{ft}^{3}$ & $\geq 15 \mathrm{ft}^{3}$ & CEE Tier II or \\
& ENERGY & $\begin{array}{l}\text { ENERGY } \\
\text { STAR labeled }\end{array}$ & III \\
\hline Refrigerator/Freezer Recycle & - & None & - \\
\hline Showerhead & - & $\begin{array}{l}\text { Evolve } \\
\text { STM labeled }\end{array}$ & - \\
& & $\begin{array}{l}\text { ShowerStart } \\
\text { Roadrunner }\end{array}$ & \\
\hline Television, $<40 "$ & - & Varies & - \\
\hline Television, $>40 "$ & - & Varies & - \\
\hline Toilet & - & $<1.28$ gal/flush & $<1.28$ gal/flush \\
\hline Water Heater, natural gas & - & $\geq 0.67$ EF & - \\
\hline Windows & Varies & - \\
\hline Note: SEER: Seasona AFUE & & \\
\hline
\end{tabular}

Note: SEER: Seasonal Energy Efficiency Ratio

AFUE: Annual Fuel Utilization Efficiency

EF: Energy Factor

CEE: Consortium for Energy Efficiency

\section{References}

1. Energy Information Administration. Average Price of Electricity to Ultimate Customers. 2012.

2. Energy Information Administration. Natural Gas Prices. 2012. 
3. United States Department of Labor Statistics. Average Energy Prices, Chicago-GaryKenosha. 2012; http://www.bls.gov/regions/midwest/newsrelease/averageenergyprices_chicago.htm.

4. United States Department of Labor Statistics. Average Energy Prices, New York-Northern New Jersey-Long Island. 2012; http:/www.bls.gov/regions/new-york-new-jersey/newsrelease/averageenergyprices_newyorkarea.htm.

5. United States Department of Labor Statistics. Average Energy Prices, Los Angeles-RiversideOrange County. 2012; http://www.bls.gov/regions/west/newsrelease/averageenergyprices_losangeles.htm.

6. Illinois Department of Natural Resources. Annual Water Use Audit Form (LMO-2). 2012; http://www.cityofchicago.org/content/dam/city/depts/water/general/Engineering/LMO2_2012.pdf.

7. New York City Department of Environmental Protection. Water Conservation Report. 2010; http://www.nyc.gov/html/dep/pdf/conservation/water_conservation_report2012.pdf.

8. Los Angeles Department of Water and Power. Urban Water Management Plan. 2010; http:/www.water.ca.gov/urbanwatermanagement/2010uwmps/Los\%20Angeles\%20Departm ent\%20of\%20Water\%20and\%20Power/LADWP\%20UWMP_2010_LowRes.pdf.

9. Carlson, Steven W. and Walburger, Adam. Energy Index Development for Benchmarking Water and Wastewater Utilities. American Water Works Association Research Foundation. 2007.

10. New York Water Environment Association. Transforming Wastewater Operations into Resource Recovery: NYCDEP's Strategies for Energy Neutral Operations. 2013.

11. Blanco, Hilda, Josh Newell, and L. Stott Alberti. Water Supply Scarcity in Southern California: Assessing Water District Level Strategies. 2012.

12. Energy Information Administration. Annual Electric Utility Data. 2015; https://www.eia.gov/electricity/data/eia923/.

13. Thornton, Julian, Reinhard Sturm, and George Kunkel. Water loss control. McGraw Hill Professional, 2008.

14. Commonwealth Edison Company. Save with Energy Efficient Rebates. 2015; https://www.comed.com/home-savings/rebates/Pages/default.aspx.

15. Consolidated Edison. Energy Efficiency: Heating and Cooling Rebates for Electric Customers. 2015; https://www.conedhvacrebates.com/hvac/electric.

16. L.A. Department of Water and Power. Rebates and Programs. 2013; https://www.ladwp.com.

17. Metropolitan Water Reclamation District of Greater Chicago. Rain Barrels. 2015; https://www.mwrd.org/irj/portal/anonymous/rainbarrel.

18. Peoples Gas. Home Energy Rebates. 2015; http://www.peoplesgasdelivery.com/home/rebates_residential.aspx.

19. Southern California Gas Company. Rebates for Your Home. 2015; https://www.socalgas.com/for-your-home/rebates/. 
CHINI ET AL. (2016)

20. City of New York. Residential Water Efficiency Programs. 2015;

http://www.nyc.gov/html/dep/html/ways_to_save_water/residential-water-efficiency.shtml. 